\title{
Brussels bids for a coordinating role on technology policy
}

Paris. The European Commission last week unveiled plans for a series of high-technology research programmes aimed at increasing the focus of European Union (EU) research on industrial and social goals.

In particular, Edith Cresson, the research commissioner, and her industry and transport counterparts, Martin Bangemann and Neil Kinnock, announced the creation of joint 'task forces' that will identify and coordinate various public and private research efforts within the member states, the EU's joint Framework research programmes and other European programmes.

The first six task forces will analyse the state of European research in educational software, vaccines and viral diseases, transport, and new generations of cars, trains and aircraft. They will then recommend research priorities based on "intensive consultation" with industry. Other task forces, for example in biotechnology, may also be created.

Although the task forces have also been asked to recommend ways to combine elements of the specific programmes within the fourth five-year Framework programme, which runs until 1999, their main impact will be to help shape priorities within the fifth Framework programme, according to commission officials.

One probable change, they say, is that, in addition to scientific quality, industrial and socioeconomic criteria will be explicitly taken into account when approving Framework projects, resulting in a "double selection procedure". Cresson says that the commission "has made rapprochement between research and industry a priority".

She adds that the task forces may eventually propose joint research programmes involving some, but not all member states, within the Framework programme, and recommend that the commission should take part in programmes run by consortia of member states outside Framework, using legal structures similar to that used to run the Airbus consortium.

But such plans are unlikely to materialize in the short term, according to one commission official, who points out that moves towards such 'variable geometry' were rejected as "premature" by the council of ministers in March. Indeed, officials have admitted that the creation of such programmes is likely to face serious "technical, political and management" problems.

The commission's plan to fund research likely to lead to commercial applications is also likely to reopen the heated debate over whether the EU should use taxpayers' money to subsidize industry, given its poor record in the past of picking winners in technology.

Declan Butler

\section{'Science and reason' forum finds enemies all around}

New York. The work of scientists is being systematically and effectively undermined by "irrationalist" critics on both extremes of the political spectrum, according to speakers at a forum held in New York last week on "the flight from science and reason".

But the forum, organized by the New York Academy of Sciences and held at the New York Academy of Medicine in Harlem, concentrated chiefly on perceived attacks from the left. Daniel Kleppner, a physicist at the Massachusetts Institute of Technology, said the most serious threat was coming from "the whole post-modernist "shtick".

The ire of Kleppner and others has been drawn primarily by social constructivism, the

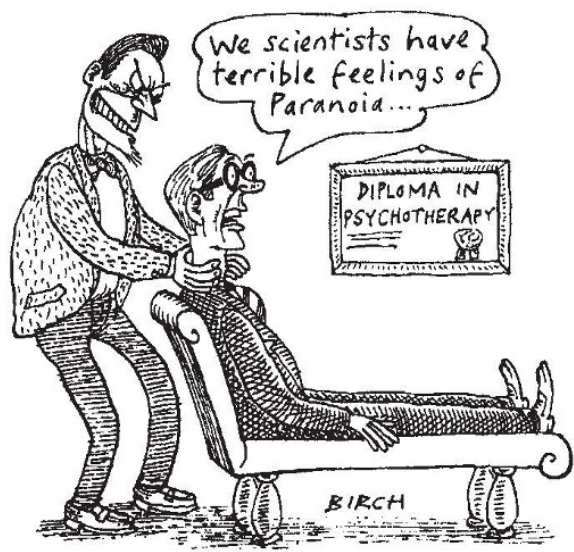

intellectual school that seeks to describe science as a collection of ideas constructed by one social group - namely natural scientists - and of no greater intrinsic value than any other such collection of ideas.

According to Norman Levitt, a mathematics professor at Rutgers University, New Jersey, who co-organized the conference, constructivists think "science is no better in its justifications than other disciplines - so it is a species of fraud ipso facto".

Speakers acknowledged that few working scientists are even aware of this assault on their worth. Nevertheless, they claimed that its pernicious effects are spreading quickly through universities and (more recently) schools, where they will eventually undermine the standing of science and medicine.

Two recent developments were seen as symptomatic of a wider malaise: the establishment of an Office of Alternative Medicine at the National Institutes of Health (see Nature 370, 591; 1994), and the allegedly constructivist leanings of draft standards for science teaching in US schools.

Paul Gross of the Centre for Advanced Studies at the University of Virginia, who organized the meeting with Levitt, said that the medical establishment, discouraged by its failure to restrict the work of chiro- practors a few years ago, had decided "not to get into a fight with [Senator Tom] Harkin over alternative medicine". Harkin - a key supporter of biomedical research — has been the most prominent supporter of the Office of Alternative Medicine.

Gross and others attacked that office, which they portrayed as an effort to exempt treatments such as acupuncture and homeopathy from the full rigours of medical science. Gerald Weissmann, of the New York University Medical Center, went further, saying that "fascists and autocrats are trying to overthrow medicine".

Gerald Holton, a Harvard physicist, said that a 1992 draft of the school science teaching standards had explicitly rejected the old, "logical positivist" model of science in favour of a constructivist one. A 1994 version omitted reference to the model, he said, but was still "peppered with social constructivist views".

By the standards contained in the new version, Holton said, "Madame Curie didn't discover radium, she constructed it". The document portrayed advances in science not in absolute terms, but as "changes in commitment of the group". Faced with such challenges, Holton argued that science must develop a better "sense of self", and act more forcibly to defend itself.

Critics of modern medicine and science - sparsely represented on the platform during the three-day event - fought back from the auditorium floor. Daniel Miller, a Brooklyn psychologist who claims some success in treating cancer patients, said the meeting was "a power structure sitting in a pretty building trying to defend itself". David Guston, a specialist in science and public policy from Rutgers, complained that speakers' characterizations of critics in the humanities had been "totally overblown".

One speaker who appeared to agree was Langdon Gilkey, a theologian at Georgetown University in Washington. "I feel the lack of a self-critical faculty here," said Gilkey. "The genuine criticisms of science have been rendered into the 'cookie' class, as if they weren't real."

He warned a science community which, he said, was more omnipotent in modern culture than it realized: "Powerful communities, unless they criticize themselves, will face mounting criticism from outside."

Dudley Hershbach, the Harvard chemist and one of three Nobel prizewinners recently 'deconstructed' in three critical television documentaries, called on scientists to show some self-effacement in dealing with criticism. Science, he said, should be "a partner of the humanities in the search for wisdom of all sorts".

Colin Macilwain 